\title{
THE EFFECT OF VITAMIN D ON CALCIUM AND PHOSPHORUS METABOLISM; STUDIES ON FOUR PATIENTS
}

\author{
By FULLER ALBRIGHT AND HIRSH W. SULKOWITCH \\ (From the Medical Service of the Massachusetts General Hospital and the Department of \\ Medicine of Harvard University Medical School, Boston)
}

(Received for publication January 21, 1938)

There are many questions which are still obscure concerning the action of vitamin D. One of the most important is whether the decrease of the calcium and phosphorus in the feces resulting from its administration is the result of increased absorption or of decreased reexcretion. This is difficult to answer unless one administers calcium or phosphorus intravenously. Whether the action is primarily on the calcium metabolism with secondary changes in the phosphorus metabolism or vice versa is also unsettled. It is likewise uncertain whether the parathyroid glands play any part in the metabolic changes following vitamin $\mathrm{D}$ administration. The present studies were undertaken to answer these and other questions.

The data come from metabolic studies on four patients. The first patient was a boy of fourteen years with a form of rickets resistant to vitamin $\mathrm{D}$ therapy. His case history was reported by Albright, Butler, and Bloomberg (1). The essential features were that in spite of what would be usually considered as adequate vitamin D therapy he had had rickets all his life; that a bone biopsy showed that the condition was actually rickets with wide osteoid seams; that the abnormalities in his calcium and phosphorus metabolism were in the same direction as those in ordinary infantile rickets, namely, a normal serum calcium level, a low serum inorganic phosphorus level, a high serum phosphatase level, and an increased excretion of calcium and phosphorus in the feces; that the usual doses of vitamin D had no effect on these abnormalities; that, however, massive doses of vitamin $D$ such as $45 \mathrm{cc}$. of viosterol $(=450,000$ I.U. (International Units)) daily did correct the abnormalities. With these large doses six changes resulted: the serum calcium and phosphorus levels were elevated; the fecal calcium and phosphorus excretions were decreased; the urinary calcium excretion was increased; and the urinary phosphorus excretion was decreased. One further point of interest to the present discussion came out of the data of another article (1). The removal of one hyperplastic parathyroid gland resulted in a prompt elevation in the depressed serum inorganic phosphorus level and a fall in the serum calcium level. This will be discussed below.

The second, third, and fourth patients were all young individuals with idiopathic hypoparathyroidism. Their case histories will appear elsewhere (2).

\section{Metabolic data on Patient 1 (M. G. H. Number $325,488)$ with rickets resistant to vitamin $D$}

In Table I are shown some data obtained during this patient's fourth admission to the Massachusetts General Hospital. The main purpose of the study was to determine whether vitamin D affects the phosphorus metabolism by increasing the absorption of phosphate from the gastro-intestinal tract or by decreasing its reexcretion. The plan was to give a large part of the phosphate intravenously without vitamin $\mathrm{D}$ administration during the control periods, to repeat with large doses of vitamin $\mathrm{D}$ during the study periods, and then, with a continuation of the vitamin $D$, to give the phosphate by mouth.

During the first two three-day periods the patient was placed on a low calcium, moderately low phosphorus diet. The results were quite surprising. Not only were the fecal calcium excretions not increased at the expense of the urinary excretions (1), but the urinary calcium excretions were excessively high. The explanation, in all probability, of this change is that it represents an after-effect of previous vitamin D therapy. Until five days before the investigation started, he had been taking $2 \mathrm{cc}$. of $2500 \mathrm{D}$ viosterol daily (200,000 I.U.). Another factor may have been that his bones were much less rachitic by that time owing to previous treatment. His phosphatase level in the serum was still high, however, 16 Bodansky units. 
TABLE I

Metabolic data on Patient 1 with rickets

\begin{tabular}{|c|c|c|c|c|c|c|c|c|c|c|c|c|}
\hline \multirow{2}{*}{$\begin{array}{c}\text { Three- } \\
\text { day } \\
\text { period }\end{array}$} & \multicolumn{4}{|c|}{ Calcium } & \multicolumn{4}{|c|}{ Phosphorus } & \multicolumn{3}{|c|}{ Serum } & \multirow{2}{*}{ Therapy } \\
\hline & Urine & Feces & $\begin{array}{l}\text { In- } \\
\text { take }\end{array}$ & $\begin{array}{l}\text { Bal- } \\
\text { ance }\end{array}$ & Urine & Feces & $\begin{array}{l}\text { In- } \\
\text { take }\end{array}$ & $\begin{array}{l}\text { Bal- } \\
\text { ance }\end{array}$ & Calcium & $\begin{array}{l}\text { Phos- } \\
\text { phorus }\end{array}$ & $\begin{array}{c}\text { Phos- } \\
\text { phatase }\end{array}$ & \\
\hline 1 & $\begin{array}{l}\text { grams } \\
0.61\end{array}$ & $\begin{array}{l}\text { grams } \\
0.08\end{array}$ & $\begin{array}{c}\text { grams } \\
0.30\end{array}$ & $\begin{array}{c}\text { grams } \\
-0.39\end{array}$ & $\begin{array}{c}\text { grams } \\
1.69\end{array}$ & $\begin{array}{l}\text { grams } \\
0.45\end{array}$ & $\begin{array}{c}\text { grams } \\
1.78\end{array}$ & $\begin{array}{c}\text { grams } \\
-0.36\end{array}$ & $\begin{array}{l}\text { mgm. per } \\
100 \text { cc. }\end{array}$ & $\begin{array}{l}\text { mgm. per } \\
100 \text { cc. }\end{array}$ & $\underset{\text { units }}{\text { Bodansky }}$ & Low calcium diet \\
\hline 2 & 0.64 & 0.08 & 0.30 & -0.42 & 1.69 & 0.39 & 1.78 & -0.30 & 10.9 (III)* & 3.0 & 16.2 & Low calcium diet \\
\hline 3 & 0.77 & 0.18 & 2.40 & +1.45 & 1.17 & 0.36 & 1.78 & +0.25 & & & & Same plus calcium lactate p.o. \\
\hline 4 & 0.77 & 0.91 & 2.40 & +0.72 & 1.11 & 0.58 & 1.78 & +0.09 & & & & Same plus calcium lactate p.o. \\
\hline 5 & 0.73 & 0.95 & 2.40 & +0.72 & 1.02 & 0.63 & 1.78 & +0.13 & & & & Same plus calcium lactate p.o. \\
\hline 6 & 0.60 & 1.10 & 2.40 & +0.70 & 2.47 & 0.50 & 3.51 & +0.54 & $\begin{array}{c}9.3(\mathrm{I}) \\
10.7(\mathrm{II})\end{array}$ & $\begin{array}{l}2.8 \\
2.6\end{array}$ & $\begin{array}{l}18.3 \\
24.7\end{array}$ & Same plus phosphate i.v. \\
\hline 7 & 0.48 & 1.16 & 2.40 & +0.76 & 2.25 & 0.61 & 3.51 & +0.65 & $10.1(\mathrm{I})$ & 2.8 & 17.3 & Same plus phosphate i.v. \\
\hline 8 & 0.43 & 0.86 & 2.40 & +1.11 & 2.23 & 0.54 & 3.51 & +0.74 & (I) & 2.6 & 20.0 & Same plus vitamin D \\
\hline 9 & 0.87 & 0.35 & 2.40 & +1.18 & 2.14 & 0.37 & 3.51 & +1.00 & $9.6($ III) & 3.1 & 15.7 & Same plus vitamin D \\
\hline 10 & 1.09 & 0.25 & 2.40 & +1.06 & 2.35 & 0.39 & 3.51 & +0.77 & & & & Same except phosphate p.o. \\
\hline 11 & 1.29 & 0.21 & 2.40 & +0.90 & 2.36 & 0.36 & 3.54 & +0.82 & $11.7(\mathrm{I})$ & 3.6 & 14.8 & Same except phosphate p.o. \\
\hline 12 & 1.35 & 0.33 & 2.40 & +0.72 & 2.41 & 0.54 & 3.54 & +0.59 & $11.6(I)$ & 4.0 & & Same without vitamin D \\
\hline 13 & 1.30 & 0.25 & 2.40 & +0.85 & 2.38 & 0.29 & 3.51 & +0.84 & $12.1(\mathrm{I})$ & 4.0 & 12.1 & Same without vitamin D \\
\hline 14 & 1.15 & 0.40 & 2.36 & +0.81 & 2.54 & 0.37 & 3.41 & +0.50 & & & & Same without vitamin D \\
\hline 15 & 1.09 & 0.85 & 2.40 & +0.46 & 2.45 & 0.75 & 3.51 & +0.31 & $11.2(\mathrm{II})$ & 3.8 & 14.9 & Same without vitamin D \\
\hline
\end{tabular}

* Roman numeral indicates on which day of period blood determination was done.

Periods 3, 4 and 5 differed from 1 and 2 in that $700 \mathrm{mgm}$. of calcium in the form of calcium lactate were given daily by mouth. As will be seen from Table I, most of this was absorbed and only a small part was excreted in the urine, the calcium balance becoming markedly positive. The fecal phosphorus was increased and the urinary phosphate excretion was markedly lowered. The blood values remained unaltered. It should be noted in passing that up to three weeks after the last viosterol treatment there was evidence of excellent absorption of calcium. This shows that the patient's resistance to vitamin $D$ therapy was not caused by a rapid destruction of the vitamin.

Periods 6 and 7 differed from the previous three in that he received $575 \mathrm{mgm}$. of phosphate intravenously daily. The fecal phosphorus excretion was not increased by this procedure, but the urinary phosphate excretion was markedly elevated. There was considerable increase in the retention of phosphorus, and the urinary calcium excretion was decreased. These data suggest that excretion of phosphorus into the gastrointestinal tract was not influenced by the pouring of a large amount of phosphate into the blood and was probably a very small factor, if existent at all, in this individual.

Periods 8 and 9 differed from the previous two in that the patient received $20 \mathrm{cc}$. of crystalline vitamin $\mathrm{D}$ in propylene glycol three times daily (=600,000 I.U.). There was a decrease in the already low fecal phosphorus excretion, without an increase in the urinary phosphate excretion, and, therefore, an increase in the phosphorus balance. Inasmuch as reexcretion seems practically ruled out in this case (v. supra) it seems certain that this change was a result of increased absorption. The fecal calcium excre- 
tion was markedly decreased and the urinary calcium excretion was considerably increased.

Periods 10 and 11 differed from the previous two only in that the $575 \mathrm{mgm}$. of phosphate which he was getting daily intravenously were given by mouth. This caused no definite change in the phosphorus excretions, there being no rise in the fecal phosphorus values. Thus the fecal phosphorus level under the conditions of this experiment was not affected when phosphate was given intravenously or when it was given by mouth; it was increased when calcium was given by mouth and it was decreased by the administration of vitamin $D$. The fecal calcium values, furthermore, were not increased by the giving of phosphate by mouth but continued their downward trend started in Period 8 with the administration of vitamin D. Thus the fecal calcium excretion was not affected by the phosphate in the diet; it was increased when the calcium was increased in the diet; and it was decreased by vita$\min \mathrm{D}$. The urinary calcium excretions continued to increase during Periods 10 and 11 and both the serum calcium and inorganic phosphorus values rose.

Periods 12, 13, 14 and 15 differed from the previous two in that vitamin $\mathrm{D}$ was discontinued. There was little reversal of trends until the last period. Then the fecal calcium excretion rose sharply, the urinary calcium excretion fell; the fecal phosphorus excretion rose and the urinary phosphate showed no significant change.

The above observations are quite clear cut. When the modus operandi of vitamin $\mathrm{D}$ is understood, it is probable that the cause of each change will be apparent. There are many theories as to the action of vitamin D and obviously it will take many experiments to prove any one. Before leaving the above data, however, it seems of interest to see which of the possible hypotheses these data support.

When vitamin D was administered in sufficient doses in this patient there resulted six metabolic sequelae: decrease of fecal calcium, moderate decrease of fecal phosphorus, increase of urinary calcium, no increase of urinary phosphate, elevation of serum calcium, elevation of serum inorganic phosphorus. In a previous experiment (1), furthermore, with the largest doses of vitamin $D$ there was apparently a definite fall in the urinary phosphorus excretion. The opposite of these changes occurred when vitamin $\mathrm{D}$ was stopped. If one assumes these five changes to be interrelated phenomena dependent on one fundamental change, the data are consistent with the hypothesis that vitamin $\mathrm{D}$ is primarily concerned with calcium (not phosphorus) and increases the absorption of calcium. Thus the sequence after vitamin $\mathrm{D}$ administration would be : (1) increased absorption of calcium causing decreased fecal calcium excretion; (2) with increased absorption of calcium an increase in urinary calcium excretion (cf. Periods 3, 4, and 5 where increased absorption of calcium due to increased intake caused increased urinary calcium excretion) ; (3) with decreased calcium in feces, an increased phosphorus absorption and hence decreased fecal phosphorus excretion (cf. rise in fecal phosphorus values in Periods 3, 4 and 5 when calcium was given by mouth); (4) with increased calcium absorption an increased deposition of the calcium-phosphatecarbonate compounds, dahlite, into the bones so that in spite of the increased phosphate absorption there is no increased urinary phosphate excretion.

So much for the four excretory changes. Before discussing the blood changes it might be well to point out that if one starts with an increased phosphate absorption as the primary action of vitamin $\mathrm{D}$ one meets with difficulties. Thus this would lead to a decreased fecal phosphorus excretion, but an increased absorption should not be followed by a decreased urinary excretion. Furthermore, since giving phosphates by mouth instead of intravenously had no effect on the fecal calcium excretions, it is hard to see how an increased absorption of phosphate in this patient could have affected the fecal calcium excretions. The increased urinary calcium excretions would be difficult to explain since the giving of phosphate intravenously decreased the urinary calcium excretions. Note, furthermore, that the fecal phosphorus excretions went from a maximum of $612 \mathrm{mgm}$. before vitamin $\mathrm{D}$ therapy down to a minimum of $358 \mathrm{mgm}$. with therapy. The corresponding figures for calcium were $1157 \mathrm{mgm}$. and $213 \mathrm{mgm}$.

How is the elevation of serum inorganic phosphorus as a result of vitamin $D$ therapy to be explained? The obvious explanation is that with 
increased absorption of both calcium and phosphorus there would be a tendency for both of these substances to rise in the serum. There are certain difficulties, however. The giving of large amounts of phosphate intravenously had no effect on the serum phosphorus level. Furthermore, during Period 6 with a serum inorganic phosphorus level of $2.7 \mathrm{mgm}$. he excreted 2465 mgm. of phosphorus in the urine; in Period 13 with a blood value of $4.0 \mathrm{mgm}$. he excreted 2376 mgm. in the urine. Thus as the blood phosphorus rose as the result of therapy, less phosphorus was excreted in the urine, or in any case there was no marked increase. The findings can be explained if one brings the parathyroids into the picture.

As pointed out in another paper (1) there is considerable evidence to suggest that the parathyroid glands are overactive in rickets. This patient's parathyroid glands were found to be hyperplastic at operation and removal of one gland was followed by a marked rise in the serum inorganic phosphorus level and a fall in the serum calcium level. This suggested that the preoperative values were kept where they were only by an excess of hormone production. When part of this production was stopped by the operation, the remaining tissue, since it was already overactive, was unable to "take up the slack." Now, if one assumes that the stimulus for parathyroid hormone production is a low serum calcium level, then as vitamin $D$ increases the calcium absorption and raises the serum calcium level, there would be less need for the parathyroid hormone. With cessation of overactivity of the glands the serum phosphorus would rise. This rise would not lead to an increased phosphate excretion in the urine, as the rising serum phosphorus level following parathyroidectomy is apparently the result of a decreased urinary phosphorus excretion (3). Thus, whereas the elevation of serum calcium is probably a result of increased absorption of calcium, the elevation of serum phosphorus may be very largely owing to a decreased level of parathyroid activity.

Even at the expense of repetition, it may be useful to see how such an hypothesis concerning vitamin $D$ fits the facts of rickets, the facts of vitamin $D$ therapy, and the facts of vitamin $D$ poisoning.
With vitamin D lack, calcium is not absorbed; the blood calcium tends to fall; this tendency is immediately met by an increased excretion of parathyroid hormone, a low blood calcium being the stimulus for parathyroid hormone production; the parathyroid hormone lowers the blood phosphorus until dahlite is being absorbed rapidly enough from the bones to keep the blood calcium normal (see another paper (1) in which it was pointed out that along with the wide osteoid seams in rickets there are areas here and there showing very rapid bone absorption). With the normal blood calcium and low blood phosphate, it is impossible to deposit dahlite where bone formation is taking place and wide osteoid seams result. With the increased fecal calcium excretion there results increased fecal phosphorus excretion. With less phosphorus being absorbed, there will be less going out in the urine, and the ratio of urine phosphorous to fecal phosphorus will be low. Inasmuch as the secondary hyperparathyroidism keeps the calcium normal and the phosphorus depressed, the bone changes will be produced especially readily with a low vitamin $\mathrm{D}$, low phosphate diet, as any increase in the phosphate in the diet will lead to increased phosphate absorption, and it is the low serum inorganic phosphorus which is causing the bone changes. Cases of rickets with a low serum calcium level as well as a low serum phosphorus level may represent examples where the parathyroid compensation mechanism has broken down. With vitamin D therapy all these changes correct themselves.

With vitamin D poisoning the calcium absorption is so rapid that the blood calcium rises above normal; this leads to a depression of parathyroid activity and a secondary hypoparathyroidism with a high blood inorganic phosphate level. With both values high there is precipitation of calcium phosphate into the soft tissues and death. The hypothesis without modification is inadequate in explaining the demineralization of the skeleton which occurs with massive doses of vitamin D. The necessary modification will be discussed below.

With this working hypothesis as to the action of vitamin $D$ and its interrelationship with parathyroid activity in mind it will be of interest to examine the second investigation. This was carried out on a boy with practically no parathy- 
TABLE II

Metabolic data on Patient 2 with idiopathic hypoparathyroidism

\begin{tabular}{|c|c|c|c|c|c|c|c|c|c|c|c|c|}
\hline \multirow{2}{*}{$\begin{array}{l}\text { Three- } \\
\text { day } \\
\text { period }\end{array}$} & \multicolumn{4}{|c|}{ Calcium } & \multicolumn{4}{|c|}{ Phosphorus } & \multicolumn{3}{|c|}{ Serum } & \multirow{2}{*}{ Therapy } \\
\hline & Urine & Feces & $\begin{array}{c}\text { In- } \\
\text { take }\end{array}$ & $\begin{array}{l}\text { Bal- } \\
\text { ance }\end{array}$ & Urine & Feces & $\begin{array}{l}\text { In- } \\
\text { take }\end{array}$ & $\begin{array}{l}\text { Bal- } \\
\text { ance }\end{array}$ & Calcium & $\begin{array}{l}\text { Phos- } \\
\text { phorus }\end{array}$ & $\begin{array}{c}\text { Phos- } \\
\text { phatase }\end{array}$ & \\
\hline 1 & $\begin{array}{l}\text { grams } \\
0.07\end{array}$ & $\begin{array}{l}\text { grams } \\
0.26\end{array}$ & $\begin{array}{c}\text { grams } \\
0.30\end{array}$ & $\begin{array}{c}\text { grams } \\
-0.03\end{array}$ & $\begin{array}{l}\text { grams } \\
0.84\end{array}$ & $\begin{array}{l}\text { grams } \\
0.63\end{array}$ & $\begin{array}{c}\text { grams } \\
1.78\end{array}$ & $\begin{array}{r}\text { grams } \\
+0.31\end{array}$ & $\begin{array}{l}\text { mgm. per } \\
100 \mathrm{cc.} \\
4.8(\mathrm{I})^{*}\end{array}$ & $\begin{array}{c}\text { mgm. per } \\
100 \text { cc. } \\
12.3\end{array}$ & \begin{tabular}{|c|} 
Bodansky \\
units \\
8.9
\end{tabular} & Control period \\
\hline 2 & 0.07 & 0.17 & 0.30 & +0.06 & 0.67 & 0.36 & 1.78 & +0.75 & $5.1($ III $)$ & 12.2 & 9.6 & Control period \\
\hline 3 & 0.05 & 0.29 & 0.30 & -0.04 & 0.60 & 0.69 & 1.78 & +0.49 & & & & Control period \\
\hline 4 & 0.09 & 0.29 & 1.93 & +1.55 & 0.39 & 0.54 & 1.78 & +0.85 & 4.5(I) & 8.0 & 12.3 & Calcium gluconate i.v. \\
\hline 5 & 0.17 & 0.24 & 1.93 & +1.52 & 0.35 & 0.42 & 1.78 & +1.01 & $5.3(\mathrm{I})$ & 9.2 & 12.2 & Calcium gluconate i.v. \\
\hline 6 & 0.07 & 0.42 & 0.30 & -0.19 & 0.50 & 0.79 & 1.78 & +0.49 & $5.4(\mathrm{I})$ & 6.5 & 13.4 & Control period \\
\hline 7 & 0.07 & 0.48 & 0.30 & -0.25 & 1.02 & 0.49 & 1.78 & +0.27 & $4.5($ II $)$ & 11.4 & & Control period \\
\hline 8 & 0.08 & 0.52 & 1.93 & +1.33 & 1.02 & 0.54 & 1.78 & +0.22 & & & & Calcium gluconate p.o. \\
\hline 9 & 0.06 & 1.70 & 1.93 & +0.17 & 1.05 & 0.98 & 1.78 & -0.25 & & & & Calcium gluconate p.o. \\
\hline 10 & 0.07 & 1.63 & 1.93 & +0.23 & 1.17 & 0.89 & 1.78 & -0.28 & $4.2(I)$ & 12.1 & 6.4 & Same plus vitamin D \\
\hline 11 & 0.06 & 1.23 & 1.93 & +0.64 & 1.17 & 0.52 & 1.78 & +0.09 & $5.8(\mathrm{II})$ & 10.4 & 5.1 & Same plus vitamin D \\
\hline 12 & 0.09 & 1.12 & 1.93 & +0.72 & 1.26 & 0.40 & 1.78 & +0.12 & 7.1(II) & 9.5 & 8.6 & Same plus vitamin D \\
\hline 13 & 0.34 & 0.87 & 1.93 & +0.72 & 1.42 & 0.39 & 1.78 & -0.03 & 9.1(III) & 8.5 & 6.9 & Same plus vitamin D \\
\hline
\end{tabular}

* Roman numeral indicates on which day of period determination was made.

roid tissue in all probability, so that the action of vitamin $\mathrm{D}$ can be divorced from secondary changes resulting from variations in parathyroid activity.

\section{Metabolic data on Patient 2 (M. G. H. Number 4636) with idiopathic hypoparathyroidism}

During the first three control three-day periods (Table II) the patient was on a low calcium, moderately low phosphorus diet. Findings typical of idiopathic hypoparathyroidism were present, namely a high serum inorganic phosphorus level (12.3 mgm. per $100 \mathrm{cc}$.), a low serum calcium level $(4.8 \mathrm{mgm}$. per $100 \mathrm{cc}$.), and a very low urinary calcium excretion.

During Periods 4 and 5 he received 1.63 grams of calcium intravenously each period in the form of calcium gluconate. ${ }^{1}$ With each injection of calcium there occurred only a transient immediate rise in the serum calcium level, the preinjection level being reached again in 12 hours. There was

$1271 \mathrm{mgm}$. of calcium were given twice daily in 250 cc. of saline. probably a tendency, however, for the serum calcium to rise over a period of days (cf. serum calcium $=4.5$ at beginning and $5.4 \mathrm{mgm}$. at end). There was a slight increase in the urinary calcium excretion but no definite change in the fecal calcium excretion. There was, therefore, a very marked rise in the calcium balance. The serum inorganic phosphorus was decreased, the urinary phosphorus excretion was markedly decreased, the fecal phosphorus excretion remained unaltered, and the phosphorus balance was markedly elevated. There seems little question that the added calcium united with phosphate and disappeared somewhere-not in the feces, possibly in the bones. It should be pointed out that a patient with idiopathic hypoparathyroidism was chosen for the determination of whether calcium given intravenously would appear in the feces because, such a patient's serum calcium level being low, there would be less loss of the injected calcium into the urine.

Periods 6 and 7 are control periods with the same régime as in Periods 1, 2 and 3. 
During Periods 8 and 9 the same amount of calcium gluconate as during Periods 4 and 5 was given, but this time by mouth. If one examines Period 9 after equilibrium had been established, one notices that most of this calcium appeared in the feces. From this it can be concluded that it was not absorbed, because from Periods 4 and 5 it was clear that had calcium reached the systemic blood system it would not have been excreted back into the feces. Inasmuch as the calcium was not absorbed there were no other changes except that the fecal phosphorus value was slightly increased as was to be expected. The serum calcium and inorganic phosphorus values on the morning following the last day of this régime were essentially the same as during the control period (4.2 and $12.1 \mathrm{mgm}$. respectively).

The stage was now set for the addition of large amounts of vitamin D. If its effect is a result of increased absorption of calcium from the gastrointestinal tract, its administration in this case should have been followed by the same changes as occurred when calcium was given intravenously. Such in most respects was the case. During Periods $10,11,12$, and 13 this patient received 6 cc. of $2500 \mathrm{D}$ viosterol daily (=600,000 I.U.). The fecal calcium excretion fell from 1.70 grams to 0.87 gram (Period 13). The serum calcium showed a definite tendency to rise, especially in the second two periods of this régime. The urinary calcium did not rise significantly until Period 13 when some critical threshold point in the serum calcium was passed. The calcium balances were markedly increased. The fecal phosphorus excretion was decreased. The urinary phosphorus excretion, however, was increased instead of being decreased. The quantities involved were such that the increased urinary excretion could be explained by increased phosphorus absorption. The serum inorganic phosphorus level fell.

These changes were very similar to the findings obtained when calcium was given intravenously and support the hypothesis that one of the main actions of vitamin $\mathrm{D}$ is to increase the absorption of calcium. There was one discrepancy, however. When calcium was given intravenously, the urinary phosphorus excretion fell about 300 mgm. per period; under the influence of vitamin $\mathrm{D}$, on the other hand, the urinary phosphorus excretion rose about $300 \mathrm{mgm}$. (Period 13). The first suggestion as to the cause of this discrepancy is that the increased absorption of phosphorus which occurs with vitamin D not only might prevent the expected drop in the urinary phosphorus excretion resulting from the increased absorption of calcium, but even might lead to the observed rise. While these data do not absolutely refute this possibility the quantities involved suggest that the urinary phosphorus excretion is too high for such an explanation. Later studies (see Experiment III) demonstrate more conclusively that such an explanation is untenable.

The fact that the serum phosphorus level fell is most significant. Under most situations the serum phosphorus rises when one gives vitamin D. If that rise is owing to an accompanying decreased activity of the parathyroid glands as hypothesized here, then in a parathyroidless patient it is clear why the rise does not occur. Furthermore, if the action of vitamin $D$ on phosphorus metabolism were primarily on its absorption from the gut, one would expect the serum phosphorus to rise with vitamin $D$ therapy even in a parathyroidless patient; the fact that it didn't supports the hypothesis that the vitamin acts primarily on calcium absorption.

This second investigation supports the hypothesis suggested from the first, but brings up the question whether something more is not happening under vitamin $\mathrm{D}$ therapy in the phosphorus metabolism than can be explained on the basis of increased calcium absorption.

\section{Metabolic data on Patient 3 (M. G. H. Number 14727) with idiopathic hypoparathyroidism}

The subject of this investigation had idiopathic hypoparathyroidism of a severe degree like the patient in the previous investigation. The data (Table III) are included in this paper to throw further light on the question discussed above whether the increased urinary phosphorus excretion resulting from vitamin $\mathrm{D}$ administration can be explained on the basis of an increased absorption of phosphorus. The patient was on a low calcium moderately low phosphorus diet to which was added 5 grams of calcium gluconate by mouth daily in divided doses.

During the three control periods (Periods 11, 12 , and 13) the expected findings were present: low urinary calcium excretion, high partition of 
TABLE III

Metabolic data on Patient 3 with idiopathic hypoparathyroidism

\begin{tabular}{|c|c|c|c|c|c|c|c|c|c|c|c|c|}
\hline \multirow{2}{*}{$\begin{array}{c}\text { Three-day } \\
\text { period }\end{array}$} & \multicolumn{4}{|c|}{ Calcium } & \multicolumn{4}{|c|}{ Phosphorus } & \multicolumn{3}{|c|}{ Serum } & \multirow{2}{*}{ Therapy } \\
\hline & Urine & Feces & Intake & Balance & Urine & Feces & Intake & Balance & Calcium & Phosphorus & Phosphatase & \\
\hline 11 & $\begin{array}{c}\text { grams } \\
0.02\end{array}$ & $\begin{array}{c}\text { grams } \\
1.19\end{array}$ & $\begin{array}{c}\text { grams } \\
1.67\end{array}$ & $\begin{array}{l}\text { grams } \\
+0.46\end{array}$ & $\begin{array}{l}\text { grams } \\
0.60\end{array}$ & $\begin{array}{c}\text { grams } \\
0.54\end{array}$ & $\begin{array}{c}\text { grams } \\
1.78\end{array}$ & $\begin{array}{l}\text { grams } \\
+0.64\end{array}$ & $\begin{array}{c}\text { mgm. per } \\
100 \text { cc. }\end{array}$ & $\begin{array}{l}\text { mgm. per } \\
100 \text { cc. }\end{array}$ & $\begin{array}{c}\text { Bodansky } \\
\text { units }\end{array}$ & $\begin{array}{l}\text { Vitamin } \\
U . S . P . \text { units }\end{array}$ \\
\hline 12 & 0.02 & 0.73 & 1.67 & +0.92 & 0.76 & 0.43 & 1.78 & +0.59 & & & & \\
\hline 13 & 0.02 & 1.18 & 1.67 & +0.47 & 0.74 & 0.43 & 1.78 & +0.61 & $6.5(I)^{*}$ & 7.6 & & \\
\hline 14 & 0.01 & 1.01 & 1.67 & +0.65 & 0.73 & 0.56 & 1.78 & +0.49 & $\begin{array}{l}6.4(\mathrm{I}) \\
5.7(\mathrm{II})\end{array}$ & $\begin{array}{l}8.7 \\
8.9\end{array}$ & & $\begin{array}{l}200,000 \\
200,000 \\
200,000\end{array}$ \\
\hline 15 & 0.02 & 0.85 & 1.67 & +0.80 & 0.92 & 0.50 & 1.78 & +0.36 & $\begin{array}{l}5.6(\text { II }) \\
6.0(\text { III) }\end{array}$ & $\begin{array}{l}8.4 \\
8.4\end{array}$ & 9.0 & $\begin{array}{l}200,000 \\
200,000 \\
200,000\end{array}$ \\
\hline 16 & 0.02 & 0.47 & 1.67 & +1.18 & 0.99 & 0.42 & 1.78 & +0.37 & $6.8(\mathrm{II})$ & 8.0 & 7.5 & $\begin{array}{l}400,000 \\
400,000 \\
400,000\end{array}$ \\
\hline 17 & 0.02 & 0.44 & 1.67 & +1.21 & 1.06 & 0.50 & 1.78 & +0.22 & $\begin{array}{l}7.6(\mathrm{I}) \\
8.1(\mathrm{II})\end{array}$ & $\begin{array}{l}8.0 \\
8.1\end{array}$ & $\begin{array}{l}7.2 \\
7.9\end{array}$ & $\begin{array}{l}400,000 \\
400,000\end{array}$ \\
\hline 18 & 0.04 & 0.28 & 1.67 & +1.35 & 1.08 & 0.30 & 1.78 & +0.40 & $9.3(\mathrm{II})$ & 7.6 & 7.5 & \\
\hline 19 & 0.05 & 0.39 & 1.67 & +1.23 & 1.07 & 0.43 & 1.78 & +0.28 & 9.5 (II) & 6.6 & 6.1 & \\
\hline 20 & 0.07 & 0.30 & 1.67 & +1.30 & 1.08 & 0.32 & 1.78 & +0.38 & $10.1(\mathrm{I})$ & 6.9 & & \\
\hline 21 & 0.08 & 0.43 & 1.67 & +1.16 & 0.91 & 0.27 & 1.78 & +0.60 & 11.7 (III) & 6.2 & & \\
\hline
\end{tabular}

* Roman numeral indicates on which day of period blood determination was done.

phosphorus in the feces, low serum calcium (6.4 mgm. per $100 \mathrm{cc}$.) and high serum phosphorus (8.7 mgm. per 100 cc.).

During vitamin D administration (200,000 to 400,000 units daily) in Periods $14,15,16$, and 17 , there was the expected decrease in the fecal calcium excretion (about $600 \mathrm{mgm}$.), a slight rise in the serum calcium level (from 6.4 mgm. per $100 \mathrm{cc}$. to $8.1 \mathrm{mgm}$. per $100 \mathrm{cc}$.), and no change in the urinary calcium excretion. The fecal phosphorus excretion showed no decided change, whereas the urinary phosphorus excretion rose decidedly, about $300 \mathrm{mgm}$. The serum phosphorus level fell slightly.

During the four control periods following cessation of vitamin D administration (Periods 18 , 19,20 , and 21 ), the same trends continued until the last period when the vitamin effect began to wear off. During these periods the fecal phosphorus excretion did show a definite decrease.

This experiment makes it quite clear that all the changes following vitamin $\mathrm{D}$ administration cannot be explained on the basis of an increased calcium absorption. It is apparently necessary to hypothesize an increased urinary phosphorus excretion as well. This latter effect may be masked in patients with intact parathyroids by a decrease in the function of the parathyroid glands (see above) which leads to a decreased urinary phosphorus excretion (cf. data on patient with rickets). In the experiment which follows, this observation concerning phosphorus excretion is even more convincingly demonstrated.

\section{Metabolic data on Patient 4 (M. G. H. Number 8568) with idiopathic hypoparathyroidism}

This investigation was essentially a repetition of the previous one except that the calcium intake by mouth was very low ( 0.30 gram per three-day period), additional calcium being administered daily in the form of calcium gluconate intravenously. The data are shown in Table IV. They 
TABLE IV

Metabolic data on Patient 4 with idiopathic hypoparathyroidism

\begin{tabular}{|c|c|c|c|c|c|c|c|c|c|c|c|c|}
\hline \multirow{2}{*}{$\underset{\text { period }}{\text { Three-day }}$} & \multicolumn{4}{|c|}{ Calcium } & \multicolumn{4}{|c|}{ Phosphorus } & \multicolumn{3}{|c|}{ Serum } & \multirow{2}{*}{ Therapy } \\
\hline & Urine & Feces & Intake & Balance & Urine & Feces & Intake & Balance & Calcium & Phosphorus & Phosphatase & \\
\hline 12 & $\begin{array}{c}\text { grams } \\
0.26\end{array}$ & $\begin{array}{c}\text { grams } \\
0.55\end{array}$ & \begin{tabular}{c|} 
grams \\
0.85
\end{tabular} & $\begin{array}{c}\text { grams } \\
+0.04\end{array}$ & $\begin{array}{c}\text { grams } \\
0.75\end{array}$ & $\begin{array}{c}\text { grams } \\
0.67\end{array}$ & $\begin{array}{c}\text { grams } \\
1.78\end{array}$ & $\begin{array}{c}\text { grams } \\
+0.36\end{array}$ & $\begin{array}{l}m g m . \text { per } \\
100 \text { cc. }\end{array}$ & $\begin{array}{c}m g m . \text { per } \\
100 \text { cc. }\end{array}$ & $\begin{array}{c}\text { Bodansky } \\
\text { units }\end{array}$ & $\begin{array}{l}\text { Vitamin } D-\bar{D} \\
U . S . P . \text { units }\end{array}$ \\
\hline 13 & 0.24 & 0.56 & 0.85 & +0.05 & 0.95 & 0.67 & 1.78 & +0.16 & $7.2(\mathrm{II})^{*}$ & 6.2 & & \\
\hline 14 & 0.26 & 0.42 & 0.85 & +0.17 & 1.12 & 0.56 & 1.78 & +0.10 & & & & \\
\hline 15 & 0.30 & 0.42 & 0.85 & +0.13 & 1.01 & 0.58 & 1.78 & +0.19 & $7.3(\mathrm{III})$ & 6.7 & & $\begin{array}{l}400,000 \\
400,000 \\
400,000\end{array}$ \\
\hline 16 & 0.33 & 0.36 & 0.85 & +0.16 & 1.59 & 0.45 & 1.78 & -0.26 & $8.6(\mathrm{II})$ & 6.4 & & $\begin{array}{l}400,000 \\
400,000 \\
400,000\end{array}$ \\
\hline 17 & 0.46 & 0.29 & 0.85 & +0.10 & 1.52 & 0.37 & 1.78 & -0.11 & $\begin{array}{l}8.8(\mathrm{I}) \\
9.0(\mathrm{III})\end{array}$ & $\begin{array}{l}6.2 \\
5.9\end{array}$ & & $\begin{array}{l}400,000 \\
160,000\end{array}$ \\
\hline 18 & 0.68 & 0.21 & 0.85 & -0.04 & 1.62 & 0.39 & 1.78 & -0.23 & 9.3(II) & 6.1 & & $\begin{array}{l}200,000 \\
400,000 \\
400,000\end{array}$ \\
\hline 19 & 0.94 & 0.13 & 0.85 & -0.22 & 1.80 & 0.31 & 1.78 & -0.33 & 9.9 (II) & 6.1 & & $\begin{array}{l}400,000 \\
400,000 \\
400,000\end{array}$ \\
\hline 20 & 1.16 & 0.18 & 0.85 & -0.49 & 1.52 & 0.42 & 1.78 & -0.16 & $\begin{array}{l}10.3(\mathrm{I}) \\
10.1 \text { (III) }\end{array}$ & $\begin{array}{l}5.3 \\
5.2\end{array}$ & & \\
\hline 21 & 1.44 & 0.17 & 0.85 & -0.76 & 1.37 & 0.34 & 1.78 & +0.07 & 9.7 (III) & 5.2 & & \\
\hline 22 & 1.52 & 0.15 & 0.85 & -0.82 & 1.78 & 0.34 & 1.78 & -0.34 & 9.9 (III) & 4.9 & & \\
\hline
\end{tabular}

* Roman numerals indicate on which day of period blood determination was done.

substantiate previous observations. In addition it should be noted that the urinary calcium excretion increased much more than the fecal calcium excretion was decreased, leading to a negative calcium balance. This again emphasizes the fact that all the metabolic changes cannot be explained by an increased calcium absorption. The mobilization of calcium in this instance is probably a sequela of the increased phosphorus excretion.

\section{DISCUSSION}

The main points have been discussed during the presentation of the data. Of the two hypothesized fundamental actions of vitamin Dto decrease fecal calcium excretion and to increase urinary phosphorus excretion-it should be noted that the former would tend to heal rickets, the latter would tend toward deminerali- zation. In all the experiments here reported, massive doses of vitamin $\mathrm{D}$ were employed. As discussed above, demineralization can occur when too large doses of vitamin $\mathrm{D}$ are given, a phenomenon which would be difficult to explain if the only action of vitamin $\mathrm{D}$ were on the calcium absorption. It, therefore, seems possible that the effect on calcium absorption (the antirachitic action) may predominate unless too large doses are administered when demineralization may occur due to the effect on phosphorus excretion.

The next question is whether the effects of vitamin $\mathrm{D}$ on calcium absorption and urinary phosphorus excretion are two separate actions of the vitamin or whether one is the more fundamental and the other secondary to it. That the phosphorus excretion cannot be the result of increased calcium absorption was demonstrated in the second experiment when it was shown that 
the giving of calcium intravenously decreased the phosphorus excretion. There remains, therefore, only the question whether the increased urinary excretion of phosphorus could lead to the decreased fecal calcium excretion. The data at hand do not give any evidence on this point. However, the parathyroid hormone causes a marked urinary excretion of phosphorus without any marked effect on calcium absorption. Furthermore, other data (4) suggest that A.T. 10 (dihydrotachysterol) has the same two fundamental actions as vitamin $\mathrm{D}$, but to different degrees. With A.T. 10 the ratio of the phosphorus excretion property to the calcium absorption property seemed greater. The fact that the degree of one phenomenon obtained in relation to that of the other varies with different drugs is evidence that one is not dependent on the other.

Certain observations from the literature are related to the observations here reported. Nicolaysen (5) found in rats that the ingestion of calcium had a marked effect in increasing the fecal phosphorus excretion, but that the ingestion of phosphorus had very little effect on the fecal calcium excretion. He likewise found that the fecal phosphorus was not increased by the parenteral injection of phosphates. In a later paper (6) this same author found that vitamin D had a marked primary action on the absorption of calcium from the gut, but no such effect on the absorption of phosphorus and that the changes in phosphorus absorption could be explained by the changes in calcium absorption. Hannon, Liu, Chu, Wang, Chen, and Chou (7), studying the effect of vitamin D in osteomalacia, found that $\mathrm{CaCl}_{2}$ administered intravenously was retained. This suggested that the high fecal calcium excretion in that condition was due to lack of calcium absorption and not to increased reexcretion. They also found that vitamin $\mathrm{D}$, when first given, affected the calcium balance out of proportion to the theoretical phosphorus balance. This suggested to them that changes in the phosphorus metabolism were the result of preceding changes in the calcium metabolism. Liu and coworkers (8) described two types of osteomalacia. In the first type there was a normal serum phosphorus, a low serum calcium, tetany, cataracts, and less bone trouble; in the second type there was a normal serum calcium, a low serum phosphorus, no tetany, and more bone disease. Vitamin D healed both types. These findings are in agreement with the theories here presented if one assumes that in the first type a secondary hyperparathyroidism failed to occur. Wilder, Higgins, and Sheard (9) believed the parathyroid hyperplasia in rickets and osteomalacia decreased the amount of bone disease. This conclusion is contrary to the theories here discussed.

Below an attempt is made to present in a diagram the rather confusing interrelations discussed in the paper:

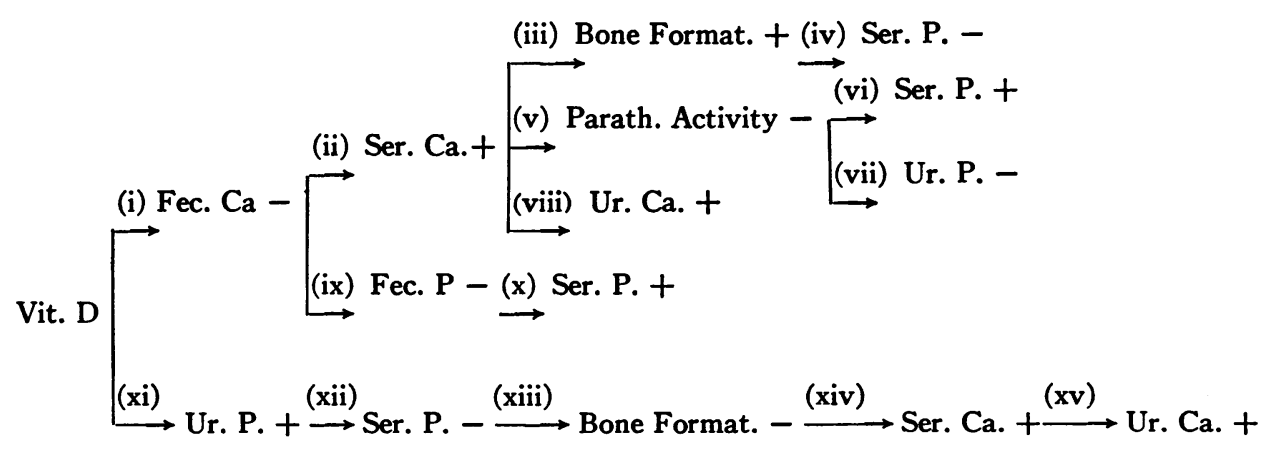

Whether the serum phosphorus level rises will depend on whether Arrows vi and $x$ are greater than iv and xii, etc.

On the basis of the serum calcium and phosphorus values three types of vitamin $D$ deficiency may be hypothesized as occurring: (a) Low calcium, normal phosphorus-where parathyroid hyperplasia has not occurred;

(b) Normal calcium, low phosphorus-where parathyroid hyperplasia has compensated for low calcium; and

(c) Low calcium, low phosphorus-where 
parathyroid hyperplasia has occurred but is unable to compensate for low calcium.

\section{SUMMARY AND CONCLUSIONS}

1. Metabolic studies were performed on four patients. Patient 1 was under treatment for a form of rickets very resistant but not intractable to vitamin D therapy; Patients 2, 3, and 4 had idiopathic hypoparathyroidism.

2. An increase in the ingested calcium in $\mathrm{Pa}$ tient 1 was followed by an increase in the fecal phosphorus excretion; however, an increase in the phosphate ingested was not followed by an increase in the fecal calcium excretion. These findings suggested that calcium in the diet has more influence on phosphate absorption than phosphate in the diet has on calcium absorption.

3. The intravenous administration of large amounts of phosphates in Patient 1 was followed by no increase in the fecal excretion of phosphate; this suggested that reexcretion of phosphate into the gastro-intestinal tract was not influenced by the amount of phosphate entering the blood. When the same amount of phosphate was given by mouth, there was likewise no increase in the fecal phosphorus excretion; this suggested that the amount of phosphate in the feces was independent of the amount of phosphate ingested. Large amounts of vitamin D, however, decreased the fecal phosphorus excretion as well as the fecal calcium excretion; these findings suggested that the fecal phosphorus excretion depends on the fecal calcium excretion and that vitamin $D$ decreased the latter.

4. Vitamin D therapy in Patient 1 , besides being followed by a decrease in the fecal excretions of calcium and phosphorus, led to an increased urinary calcium excretion, no increase in the urinary phosphorus excretion, and an elevation of both calcium and inorganic phosphorus in the serum. The findings seemed consistent with the hypothesis that vitamin D increased the absorption of calcium, the other sequelae being secondary to this phenomenon. The added proviso was necessary that with the rising serum calcium level there occurred a decreased activity of the parathyroid glands (see below).

5. The fact that with the administration of vitamin $\mathrm{D}$ the serum inorganic phosphorus value rose, whereas the urinary phosphorus excretion remained stationery or even fell, strongly suggested that the rise in the inorganic phosphorus level was owing to an accompanying decreased activity of the parathyroid glands as a result of therapy (cf. decreased urinary phosphorus excretion and rising inorganic phosphorus level in serum with parathyroidectomy). That the rise in serum inorganic phosphorus level was not due merely to increased absorption of phosphorus was shown by its failure to occur when phosphate was administered intravenously.

6. In Patient 2 the intravenous administration of calcium was followed by no increase in the calcium excretion in the feces; the same amount of calcium given by mouth caused a marked increase in the fecal calcium excretion. Since vitamin $\mathrm{D}$, thereafter, decreased the calcium excretion in the feces it was concluded that this was owing to increased absorption of calcium and not to decreased reexcretion into the gastro-intestinal tract.

7. In Patients 2, 3, and 4 with probably no functioning parathyroid tissue, vitamin $\mathrm{D}$ therapy was followed by a falling serum inorganic phosphorus level. This is further evidence that the rise in inorganic phosphorus which usually follows vitamin D therapy is the result of an accompanying decreased activity of the parathyroid glands.

8. In Patients 2, 3, and 4, the administration of large amounts of vitamin $\mathrm{D}$ was followed by an increase in the urinary phosphorus excretion greater than could be explained by the decreased fecal phosphorus excretion. This seemed to necessitate the added hypothesis that vitamin $\mathrm{D}$ in addition to increasing the absorption of calcium increases the urinary excretion of phosphorus. It is probably because of this property of vitamin $\mathrm{D}$ that one gets demineralization with large doses.

9. A tentative diagram is presented for the relation to one another of the various sequelae following vitamin $\mathrm{D}$ therapy.

10. On the basis of the serum calcium and phosphorus values three types of vitamin $\mathrm{D}$ deficiency are differentiated: (1) without parathyroid hyperplasia, (2) with compensatory hyperplasia, and (3) with hyperplasia, insufficient to cause compensation. 


\section{BIBLIOGRAPHY}

1. Albright, F., Butler, A. M., and Bloomberg, E., Rickets resistant to vitamin D therapy. Am. J. Dis. Child., 1937, 54, 529.

2. Drake, T. G., Albright, F., Bauer, W., and Castleman, B., Chronic idiopathic hypoparathyroidism; report of seven cases with autopsy findings in one ( $T o$ be published).

3. Albright, F., and Ellsworth, R., Studies on the physiology of the parathyroid glands. I. Calcium and phosphorus studies on a case of idiopathic hypoparathyroidism. J. Clin. Invest., 1929, 7, 183.

4. Albright, F., Bloomberg, E., Drake, T., and Sulkowitch, H. W., A comparison of the effects of A.T. 10 (dihydrotachysterol) and vitamin $\mathrm{D}$ on calcium and phosphorus metabolism in hypoparathyroidism. J. Clin. Invest., 1938, 17, 317.

5. Nicolaysen, R., Studies upon the mode of action of vitamin D. II. The influence of vitamin D on the faecal output of endogenous calcium and phosphorus in the rat. Biochem. J., 1937, 31, 107.

6. Nicolaysen, R., Studies upon the mode of action of vitamin D. III. The influence of vitamin D on the absorption of calcium and phosphorus in the rat. Biochem. J., 1937, 31, 122.

7. Hannon, R. R., Liu, S. H., Chu, H. I., Wang, S. H., Chen, K. C., and Chou, S. K., Calcium and phosphorus metabolism in osteomalacia. I. The effect of vitamin D and its apparent duration. Chinese M. J., 1934, 48, 623.

8. Liu, S. H., Hannon, R. R., Chu, H. I., Chen, K. C., Chou, S. K. and Wang, S. H., Calcium and phosphorus metabolism in osteomalacia. II. Further studies on the response to vitamin D of patients with osteomalacia. Chinese M. J., 1935, 49, 1.

9. Wilder, R. M., Higgins, G. M., and Sheard, C., The significance of the hypertrophy and hyperplasia of the parathyroid glands in rickets and osteomalacia. Ann. Int. Med., 1934, 7, 1059. 